\title{
Interplay Between Reservation Wage and Unemployment Duration: Evidence from Jordan, Serbia, Montenegro, Ukraine and Moldova in 2015
}

\author{
Tereza Kochovska PhD. Cnd. \\ Finance Think-Skopje, Economic Research and Policy Institute \\ Frederic Shopen 1/2, 1000 Skopje, Macedonia \\ Tel: 389-7820-8593Ｅ-mail: tereza_kocovska@hotmail.com
}

Received: November 15, 2019 Accepted: December 4, 2019 Published: December 11, 2019

doi:10.5296/ber.v10i1.15821

URL: https://doi.org/10.5296/ber.v10i1.15821

\begin{abstract}
This study investigates the reservation wage along with the unemployment duration of the youth in five countries from three groups of countries, the MENA countries, the WB countries and the CIS countries. The study assesses the determinants of the reservation wage and in particular how it is related to unemployment duration. The data comes from the School to Work Transition Survey in 2015 which is a survey that is labor market designed and includes labor market information on young people aged 15 to 29 years. The Two Stage Least Square (2SLS) model is conducted by using instrumental variables. This technique is used since we suspect that ednogeneity between the reservation wage and the unemployment duration is possible in our model. The results suggest the interplay between the reservation wage and the unemployment duration is countercyclical, the longer the unemployment duration the lower the reservation wage. Youth that lives in a household that receives other sources of income and remittances have lower reservation wages and youth that comes from a household with good financial situation and receives governmental financial assistance have higher reservation wages. Married youth with children have higher reservation wage and lower unemployment duration and more educated and trained youth has higher reservation wage.
\end{abstract}

Keywords: Reservation wage, Unemployment duration, 2SLS model, Youth unemployment, Remittances 


\section{Introduction}

The reservation wage is an issue that is very closely related to the unemployment rate, unemployment duration and placement of workers in the labor market. The reservation wage is the lowest wage that a worker is prepared to accept. Mohanty (2005) states that the reservation wage is the most important determinant of the labor supply in modern labor economics.

From an economic point of view, and more specifically through the prism of labor market, the Middle East and North Africa (MENA) countries, the Western Balkans (WS) countries and the Commonwealth of Independent States (CIS) can be tied up by one term - the youth unemployment. The significant rates of youth unemployment in these countries are directly connected with the unemployment duration and the reservation wages of this youth population.

The CIS average youth unemployment rate in 2012 was recorded as $14.5 \%$. The employment rate, on the other site is relatively low for young people (15-29) compared to the total population. From 2014-2017 in Moldova the employment rate fluctuates from 28-33.3\%. The latest recorded youth unemployment rate in Ukraine by ILO is $19.63 \%$ in 2018, even thou it had its peak in 2014 and 2016 by reaching over $23.26 \%$ and $23.14 \%$ respectively. The Middle East and North Africa (MENA) also have relatively high youth unemployment rates of $28.2 \%$ and $30.5 \%$, respectively, in 2014 but the rates have continued to worsen since 2012, particularly for young women. Later on, Jordan takes the lead by reaching 37.24\% in 2018 . Last but not least is the Western Balkan (WB). According to the International Labour Organization (ILO) (2015), Balkan countries have been facing extremely high level of youth unemployment after 2008. In 2015, according to ILO (2015) the average unemployment rate among young people in EU member states is around $21 \%$. Contrary to that in Serbia it even reaches around $50 \%$ and in Montenegro around $40 \%$, which is more than double above the EU average.

The data used for this research comes from the latest School to Work Transition Survey (SWTS) which is a survey that is labor market designed. It includes labor market information on young people aged 15 to 29 years. This survey has crucial information because the structure of the survey is focused on the transition from school to work, which is a main focus of this research. An important aspect of the survey is that SWTS detects the individual characteristics of young people that determine labor market disadvantage. Furthermore, it collects information for the labor market for the least developed countries, which do not have databases of such. Thus, the structure of the survey enables this research to contribute by determining the relationship of the reservation wage and the unemployment duration, but also an identification of the determinants of the reservation wage to a such young sample, and see the differences from the whole populations analysis. The data that this study will cover includes five countries from three groups of countries: MENA, WB and CIS countries, all in 2015. The data for MENA countries refers to: Jordan - 2015. In the Western Balkan countries are included Serbia -2015 and Montenegro - 2015, and CIS include Moldova - 2015 and Ukraine - 2015. 
This paper will be developed in three sections. First, a literature review will be presented for the interplay between the reservation wage and the unemployment duration which also elaborates the other determinants of the reservation wage. Then, descriptive analysis will be provided, so that in the end the results of the empirical analysis will be discussed along with policy recommendations in the conclusion section.

\section{Literature Review}

The theoretical background of this research is based on the job search theory of analyzing the frictional unemployment resulting from job hunting by workers (Haurin and Sridhar, 2003). The reservation wages along with the job search are important in shaping the labor market transitions between different statuses, transfer from passive workers to active job searchers, to employed persons, but however they are rarely directly observed. This concept is important for analyzing key aspects of labor market dynamics. More specifically, the reservation wage is a concept that has a relevance for modeling labor supply decisions, through its influence on transitions from non-employment to employment. Moreover, the reservation wage sets the grounds of the job search theory where a person stops its search for a job under conditions of uncertainty and imperfect information. When analyzing and understanding in both fields - macroeconomics (participation of workers on the labor market) and microeconomics (personal decisions of workers when to stop the job search) - the influence of the reservation wage is of considerable importance from both analytical and policy perspectives. What the literature does not weight on either side is the relationship of the reservation wage and the unemployment duration. Addison et al. (2009) stated that there is a positive influence of the unemployment duration on the reservation wage, while they already know the positive influence of the reservation wage on the duration with certainty. Sants (1977) complements to the concept of this relationship by stating: 'The higher the reservation wage, ceteris paribus the lower the probability of finding an acceptable wage offer, and the longer would be the expected duration of unemployment.' Contrary to the statements of positive relationship of the reservation wage and the unemployment duration, a recent study of Krueger and Mueller (2014) finds that reservation wages appear to influence employment decisions among unemployment insurance recipients in New Jersey, but reservation wages are unaffected by unemployment duration and unemployment insurance exhaustion. In the study of Christiansen (2001), no evidence of an influence of unemployment duration and different kinds of unemployment benefits on reservation wages was found for Germany. Again, this finding is in contrast to theoretical models predicting declining reservation wages with increasing unemployment duration. Only in countries with rapidly declining and exhausting unemployment benefits an obvious decline of reservation wages with duration of unemployment is expected (Dolton and O'Neill, 1995). Therefore, the presented results for Germany, which show no declining reservation wages, may simply indicate a low financial pressure to unemployed persons. Malk (2014) and Hofler and Murphy (1994) elaborate the reservation wage fluctuations taking into account the individual characteristics such as age, gender, education, qualifications and experience. Higher education, specifically having a degree (undergraduate or post-graduate), is associated with a lower duration of unemployment and lower unemployment duration is associated with higher 
reservation wage (Addison et al., 2013). De Coen (2015) concludes that women have lower reservation wages than man. Opposite to this, Queralt (2006) concluded that when reservation wages are the same for both men and women, highly educated women are able to receive job offers at the same frequency as highly educated men, which equalizes the reservation wages of men and women in case of high education. An increase in a person's experience is expected to increase his wage expectations, and this is in line with previous studies since experienced people rationally assume their productivity will be higher than that of inexperienced people. In addition, previous job experience enhances a person's perception about his productivity and raises his wage expectation (Şentürk, 2015). The conclusion is that the more competitive the worker, the higher the probability a job offer to be received, the higher the reservation wage. Additionally, Prasad (2003) concludes that the variables that proxy for alternative sources of income, including total net household income and a dummy for receipt of unemployment compensation, are positively correlated with reservation wages. The main other sources of income according to Malk (2014) are wealth, income of spouse and other family members and unemployment benefits. The relationship between the other sources of income and the reservation wage is positive. The higher the income in the household the higher the reservation wage. Lamers (2014) investigates the relationship of wealth and reservation wage, but also the job search, and his results suggest that wealth has a significantly positive effect on reservation wages of both household heads and spouses, and a significantly negative effect on the search effort of household heads. The study of Lentz \& Tranaes (2005) suggests that wealth and other income sources may affect search intensity. And so the presence of these alternative sources of income could be expected to affect reservation wages through their effect on the duration of unemployment (Malk, 2014). Furthermore, Prasad (2003) and Maani and Studenmund (1986) analyze the factors that may influence the search period. They conclude that in the first place are the economic resources. The same reasoning is behind the unemployment benefits. As unemployment benefits increase the reservation wage increases as well (Beladi and Kar, 2013). Theoretically this leads to a point at which sufficiently high unemployment benefits would eventually eliminate all economic activity (Beladi and Kar, 2013). Shimer and Werning (2006) analyzed the length of the unemployment benefits. They state that usually the assumption is that benefits last forever. But in reality most unemployment benefit systems pay only for a specified amount of time. Raising benefits will actually lower such a worker's reservation wage since it encourages one to accept a mediocre job in order to renew eligibility (Carolina and Pau, 2008). Wealth and the income of a spouse or other family member increase the reservation wages. The higher amount of unemployment benefits pushes the reservation wage to go higher, but, what matters is the duration of the unemployment benefits that is if they are for finite length of time, than the effect is opposite.

\section{Model and Data}

The main empirical specification has the following form:

$$
\operatorname{lnRW}_{i}=B_{o}+B_{1} \mathrm{UD}_{i}+B_{2} \mathrm{R}_{i}+B_{3} \mathrm{~N} i+B_{4} \mathrm{UB} i+B_{5} \mathrm{FS}_{i}+B_{6} \mathrm{MS} i+B_{7} \mathrm{Ed} i+B_{8} \mathrm{OS} i+E i
$$

Where, $\ln R W$ is the natural logarithm of the reservation wage of the individual, $U D$ is the 
instrumented unemployment duration of the individual in the first stage, $R$ is dummy if the individuals' household receives remittances, $N$ is dummy if the individual falls into the category of not in employment, education or training (NEETS), $U B$ is dummy if the individual uses government unemployment help, $F S$ represents the financial situation of the household from where the individual comes, $M S$ is a dummy of the marital status of the individual, $E d$ presents the level of education of the individual, $O S$ is a dummy of weather the individual receives other sources of income within a family, and $E$ - error term. In each abbreviation, $i$ refers to each individual surveyed and $B$ in front of each variable is the coefficient of the regression, concerning that variable.

As discussed in the Literature section, our main variables of interest, reservation wage and unemployment duration, may be suspected for endogeneity in the model. Namely, the error term of the reservation wage may be directly connected with the explanatory variables of the unemployment duration. In order to overcome it, the unemployment duration is instrumented by variables that do not influence the error term of the reservation wage directly, and then the reservation wage is regressed on the instrumented unemployment duration. Thus, we rely on 2SLS model with IV technique in the empirical estimation, where the first stage has the following form:

$$
\mathrm{UD}_{i}=B_{o}+B_{1} \mathrm{~A} i+B_{2} \mathrm{NoC}_{i}+B_{3} \mathrm{G}_{i}+E u d_{i}
$$

The independent variables that instrument the unemployment duration are as follows: $A$ that represents a continuous variable of the age the individual, $N o C$ is a continuous variable of how many children has the individual reported and $G$ represents a dummy of the gender of the individual. Eund is the error term in the first stage of the regression. The term $i$ refers to each individual surveyed.

The SWTS is a survey that is labor market designed. It includes labor market information on young people aged 15 to 29 years. This survey has crucial information because the structure of the survey is focused on the transition from school to work, which is of matter of this research. According to ILO's information for implementation of this survey, they state that the SWTS was designed in a way that applies a stricter definition of "stable employment" than is typically used in the genre. The SWTS offers important additional information over traditional labor force surveys. An important aspect of the survey is that SWTS detects the individual characteristics of young people that determine labor market disadvantage. Also, it identifies the features of youth labor demand. This demand compared to the supply on the labor market introduces the mismatch that is happening on the labor market. Furthermore, it collects information for the labor market for the least developed countries, which do not have databases of such.

The structure of the SWTS is divided into 7 sections, according to the characteristics and nature of the questions: section A- Reference details, section B - Personal, family and household information, section C - Education, activity history and aspirations, section D Youth in education, section E - Unemployed youth, section F - Young employees and section $\mathrm{G}$ - Youth not in the labour force. 


\section{Mll Macrothink}

Business and Economic Research ISSN 2162-4860 2020, Vol. 10, No. 1

The selection of the sample of analysis treats only unemployed workers. The variables that will be used in the research are primarily the socio-demographic variables. As previously explained in the literature review this research will identify relationship between these variables and the reservation wage i.e. how they influence the reservation wage individually and whether they influence the reservation wage at all if combined with the other variables. Furthermore, information of the sources of income of the respondent is collected. A focus is put on the variable remittances, analyzing if the reservation wage of the youth is influenced if the household receives remittances from abroad. Moreover, in the determinants of the other sources of income benefits or financial help from the government for being unemployed are treated.

Our dataset for the model consists of five countries from the three categories of countries: MENA, WB and CIS countries that have conducted the SWTS in 2015. The sources of the data employed in the analysis include the latest data from the SWTS provided by ILO on micro level for each country. In the sample of the MENA countries is included: Jordan. In the category of Western Balkan countries are included Serbia and Montenegro. Two countries from the category of CIS countries were covered with the SWTS by ILO in 2015 and those are: Moldova and Ukraine.

Table 1. Descriptive statistics of the sample

\begin{tabular}{|l|l|l|l|l|}
\hline All countries & Age & No of children & $\begin{array}{l}\text { Unemployment } \\
\text { duration (months) }\end{array}$ & $\begin{array}{l}\text { Reservation } \\
\text { wage (EUR) }\end{array}$ \\
\hline Mean & 21.6 & 0.26 & 19.62 & 252.53 \\
\hline Standard Deviation & 4.18 & 0.68 & 2.20 & 196.86 \\
\hline Range & 14.00 & 7.00 & 7.00 & 3760.34 \\
\hline Minimum & 15.00 & 0.00 & 1.00 & 2.51 \\
\hline Maximum & 29.00 & 7.00 & 8.00 & 3762.85 \\
\hline Count & 14537 & 14537 & 3419 & 4905 \\
\hline
\end{tabular}

Source: ILO, calculation of the author

In table 1 are presented the descriptive statistics of the sample. It includes respondents of age in range of 15-29. The average age of the total sample is 21.6 years and on average the respondents have 0.26 children. On average, these respondents are unemployed 19.62 months and have a reservation wage of 252.53 euros per month. On the other hand, there are also responders that stated that have no unemployment duration. This phenomenon is referred to the transition from one job to another.

Table 2. Average reservation wage and average unemployment duration

\begin{tabular}{|l|l|l|l|l|l|l|}
\hline & All countries & Jordan & Serbia & Montenegro & Ukraine & Moldova \\
\hline ARW (EUR) & 252.53 & 403.08 & 225.5 & 317.37 & 75.7 & 165.07 \\
\hline AUD (months) & 19.62 & 6.24 & 31.8 & 33.48 & 16.8 & 15 \\
\hline
\end{tabular}

Source: ILO, calculation of the author 


\section{Ml Macrothink}

Business and Economic Research ISSN 2162-4860 2020, Vol. 10, No. 1

In table 2 are presented the average reservation wages and the average unemployment durations of each of the five countries, compared with the total average reservation wage and unemployment duration of all five countries. The highest reservation wage appears to be in Jordan, 403.08 euros per month and also here respondents have the shortest unemployment duration of 6.24 months. The lowest reservation wage is reported in Ukraine with 75.7 euros per month, followed by Moldova, Serbia and Montenegro. The longest unemployment duration is reported in Montenegro with on average 33.48 months, followed by Serbia Ukraine and Moldova.

Table 3. Description of the variables

\begin{tabular}{|l|l|l|}
\hline Gender & Absolute no. & \% \\
\hline female & 7160 & $49.25 \%$ \\
\hline male & 7378 & $51.75 \%$ \\
\hline Marutal status & & \\
\hline single & 8771 & $60.33 \%$ \\
\hline married & 5767 & $39.67 \%$ \\
\hline Education & & \\
\hline primary education & 11158 & $76.75 \%$ \\
\hline secondary education & 2764 & $19.01 \%$ \\
\hline tertiary education & 616 & $4.24 \%$ \\
\hline Reported children & & \\
\hline with children & 2374 & $16.32 \%$ \\
\hline without children & 12164 & $83.67 \%$ \\
\hline Falls into category of NEETS & & \\
\hline NEETS & 2916 & $20.05 \%$ \\
\hline Not NEETS & 11622 & $79.95 \%$ \\
\hline Receives remittances & & \\
\hline Remittance receivers & 1094 & $7.5 \%$ \\
\hline Non receivers & 1344 & $92.5 \%$ \\
\hline
\end{tabular}

Source: ILO, calculation of the author

Table 3 describes the variables of the sample that includes all five countries. The distribution of the sample according to gender is $51.75 \%$ male and $49.25 \%$ female. $60 \%$ of the sample is single, and this includes the divorced and widowed respondents as well, the other $30 \%$ of the sample live as a couple, regardless if they are in a formal marriage. $76.75 \%$ of the sample is with primary education and only $4.24 \%$ is with tertiary. $16.32 \%$ of the respondents have at least one child. Regarding the two specific variables of interest in this paper, the first one, whether the respondent falls into the category of NEETS or not, and the second one, whether the family of the respondent receives remittances, turns out that $20 \%$ of the sample falls into the category of NEETS and only $7.5 \%$ are remittance receivers. 


\section{Results}

We discuss, firstly, the diagnostics of the model since we use the instrumental variable approach. In order to confirm the validity of the instrumental variables and the validity of the model for the regression as a whole, two tests are applied. Firstly, we use the Sargan-Hansen test which is a test of overidentifying restrictions. The joint null hypothesis of the test is that the instruments are valid instruments, i.e., uncorrelated with the error term, and that the excluded instruments are correctly excluded from the estimated equations. The p-value (0.29) of the Sargan-Hansen test in our estimation is higher than 0.05, concluding that the instruments are valid.

The second test is the underidentification test. The underidentification test is an LM test of whether the equations are identified with the selected independent variables as instrumental variables, i.e., that the excluded instruments are relevant and are correlated with the endogenous repressors. When conducting this test, under the null hypothesis is stated that the equation is underidentified. The LM statistic has a p-value of 0.000 in the regression, thus we can reject the null hypothesis and conclude that the model is identified.

Table 4. First stage regression

\begin{tabular}{|l|l|}
\hline \multicolumn{2}{|l|}{ Unemployment duration - dependent variable } \\
\hline Age & $0.11^{* * *}$ \\
\hline & $(0.014)$ \\
\hline Number of children & $-0.3 * * *$ \\
\hline & $(0.79)$ \\
\hline Gender & -0.05 \\
\hline & $(0.086)$ \\
\hline constant & $1.56 * * *$ \\
\hline & $(0.38)$ \\
\hline observations & 2334 \\
\hline Sanderson-Windmeijer F-test & $22.77 * * *$ \\
\hline
\end{tabular}

Source: Authors' calculations *, **, *** denote statistical significance at the 10,5 , and $1 \%$ level, respectively. The number in the brackets represents the standard error of the representative coefficient.

Source: ILO, calculation of the author

In the first stage of the 2SLS model the unemployment duration is regressed in order to be instrumented. The results suggest that two of the three instruments: age and number of children are statistically significant. Each additional year of age increases the unemployment duration by 1 half year, and every additional child reported decreases the unemployment duration by 3 half years. Regarding the conclusion of the coefficient of this variable a specific fact has to be taken into consideration. The sample in the model is a young sample up until age 29, when having children, the existential needs increase within a household, so the need a 


\section{Macrothink}

Business and Economic Research

ISSN 2162-4860

2020, Vol. 10, No. 1

parent to be placed on the labor market results in accepting any job offer by the youth, eventually resulting in lowering the unemployment duration.

Table 5. Second stage regression

\begin{tabular}{|l|l|}
\hline \multicolumn{2}{|l|}{ Reservation wage- dependent variable } \\
\hline Unemployment duration & $-0.19^{* * *}$ \\
\hline & $(0.047)$ \\
\hline Remittances & $-0.31^{* * *}$ \\
\hline & $(0.086)$ \\
\hline Other sources of income & $-0.38^{* * *}$ \\
\hline & $(0.064)$ \\
\hline Marital status & $0.26^{* * *}$ \\
\hline & $(0.038)$ \\
\hline NEETS & $-0.46^{* * *}$ \\
\hline & $(0.056)$ \\
\hline Unemployment government help & $0.37 * * *$ \\
\hline & $(0.088)$ \\
\hline Financial situation & $0.199^{* * *}$ \\
\hline & $(0.056)$ \\
\hline Education & $0.35^{* * *}$ \\
\hline & $(0.032)$ \\
\hline constant & $5.028^{* * *}$ \\
\hline & $(0.199)$ \\
\hline observations & 2334 \\
\hline LM statistic (Anderson canon.corr) & $66.66^{* * *}$ \\
\hline Sargan statistic & 2.418 \\
\hline
\end{tabular}

Source: Authors' calculations *, **, *** denote statistical significance at the 10,5 , and $1 \%$ level, respectively. The number in the brackets represents the standard error of the representative coefficient.

Source: ILO, calculation of the author

In the second stage of the 2SLS model the reservation wage is regressed with the instrumented unemployment duration from the first stage. All the independent variables are statistically significant at a confidence level of $99 \%$. The results suggest that for every additional semi-year of unemployment duration the reservation wage decreases by $19 \%$ * implying a countercyclical relationship between these two variables, which is along with the previously elaborated literature.

\footnotetext{
${ }^{*}$ The interpretation of the coefficients is calculated in the following way: the coefficient is expatiated, subtracted by one from this number, and multiplied by 100. This gives the percent increase (or decrease) in the response for every one-unit increase in the independent variable due to the fact that only the dependent variable is log-transformed.
} 
Alternative income during the period of unemployment raises reservation wage of such individuals whereby lowering the probability of accepting the job offer and the probability of re-employment. Various kinds of non-labor income during a period of unemployment including household income, state and private transfers, investments, savings, etc. are likely to have the same effect on duration of unemployment as casual labor income reducing the probability of reemployment and thereby extending the period of unemployment. However, existence of other sources of subsistence during a period of unemployment including income from casual work activities and subsidiary farming, household income and state transfers significantly lowers the probability of re-employment almost by the same amount. This effect is consistent with job search theory. However, in the second stage of the regression the main additional source that is included in this variable of other sources is the support from a family member, especially parents of the youth. Additionally, all these sources of income, including the remittances are not directly provided to the youth of matter in the modeling. The youth comes from a household that receives other sources of income, and the direct receiver is the head of the household, not necessarily the young person, which is contrary to the literature assessment of the reservation wage and the other sources of income. The effect of the other sources of income is countercyclical with the reservation wage of this youth, by lowering the reservation wage by $32 \%$, meaning receivers of other sources of income have $32 \%$ lower reservation wage than non-receivers.

These countries tend to be remittance dependent. The influence of the remittances has negative effect on the reservation wage. The individuals that fall into the category of remittance receivers have lower reservation wage by $27 \%$. The youth that receives other sources of income and remittances tend to come from socially vulnerable households pressuring them to be placed on the labor market as soon as possible, putting them into a position of accepting any job offer resulting in lowering their reservation wage. Having a governmental help or some kind of state financial assistance suggests that receivers tend to have higher reservation wage than non-receivers by $44 \%$. The two differences between this additional income from the other ones is that the governmental financial assistances are provided for a finite period of time and are provided directly to the surveyed individuals. The results also suggest that if the young person comes from a household with good financial situation, he or she will have higher reservation wage by $20 \%$ in this case.

The youth who is married have tendency of increasing their reservation wage. As a matter of fact, married youth has $29 \%$ higher reservation wage then single youth. Along with the literature, a young person treats the spouse's salary as an additional income whose direct receiver is the young person.

When considering the education concept for this model, it can be concluded that as the time passes of a person in the education system the higher the level of learning and education, making a young person more competitive to be placed on the labor market, the higher the reservation wage. The higher education increases the reservation wage by $41 \%$. On the other hand, if a person falls into the category of NEETS has $44 \%$ lower reservation wage than the ones that don't fall into this category, which is in line with the literature review and suggests that less competitive youth has lower reservation wages. 


\section{Conclusion}

The issues of unemployment, youth unemployment and placement of the youth on the labor market had raised concerns recently not only in developing countries but in the developed too. This issue has spread in most regions in Europe and beyond, covering the Western Balkans, MENA countries and the CIS countries. Besides the fact that the reservation wage and the unemployment duration are two phenomena that are not as closely analyzed in the developing countries as in the developed countries, they are directly connected with the placement of the youth on the labor market and the youth unemployment rate, and require thorough and careful assessment. In particular, this paper has a twofold aim. First to investigate the relationship of the reservation wage and the unemployment duration and second to investigate the determinants of the reservation wage of the five countries coming from MENA, WB and the CIS countries. The analysis covers year 2015, the latest year when the SWTS was conducted in these countries. The five countries have two things in common being developing countries and having a high youth unemployment rate.

The findings of this study suggest that longer unemployment duration decreases the reservation wage. The relationship of the two crucial variables in this study is countercyclical. This is due to the offsetting results of the period of unemployment duration, decreasing youths' competence. Additional to the unemployment duration, what determines the reservation wage are the other sources of income, complemented with remittances and governmental financial assistance as separate sources of income. The other sources of income and the remittances decrease the reservation wage, given that most of the remittance dependent households are socially vulnerable, with youth striving to be placed on the labor market by accepting any job offer. Additionally, this youth is not a direct receiver of the other sources of income within the household, except the governmental financial assistance, which is provided for a finite period of time, affecting positively the reservation wage, same as if the young person comes from a household with good financial situation. Taken separately, the socio-demographic variables also affect the reservation wage, particularly the education. Findings of the study concluded that the more competitive (educated and trained) a young person is, the higher reservation wage he/she has and vice versa. Last but not least, is the family status of the young person, considering if he/she is married and/or has children. The results suggest that married people have higher reservation wages and youth with children have lower unemployment duration. This suggests that living in a community with children increases the existential needs, pushing the young person to be placed on the labor market as soon as possible, decreasing the unemployment duration and spouses' income gives support to the young person resulting in increasing the reservation wage.

A recommendation for further analysis is to broaden the analysis of a sample that includes not only youth that is unemployed, but also elders that are unemployed and to compare how the same variable influence the two groups of unemployed people.

\section{References}

Addison, J. T., Centeno, M., \& Portugal, P. (2009). Do reservation wages really decline? Some international evidence on the determinants of reservation wages. Journal of labor 
research, 30(1), 1-8. https://doi.org/10.1007/s12122-008-9057-y

Addison, J. T., Machado, J. A., \& Portugal, P. (2013). The reservation wage unemployment duration nexus. Oxford Bulletin of Economics and Statistics, 75(6), 980-987.

https://doi.org/10.1111/j.1468-0084.2012.00717.x

Beladi, H., \& Kar, S. (2013). Unemployment Benefit and Nascent Entrepreneurship. UTSA, College of Business. https://doi.org/10.1111/jere.12023

Christensen, B. (2001). The Determinants of Reservation Wages in Germany Does a Motivation Gap Exist? (No. 1024). Kiel Working Paper. [Online] Available:

https://www.econstor.eu/handle/10419/17739

Carolina, M., \& Pau, L. (2008). The Reservation Wage of Unemployed Job Seekers in Curaçao. [Online] Available:

https://sta.uwi.edu/conferences/09/salises/documents/L\%20Pau.pdf

De Coen, A., Forrier, A., \& Sels, L. (2015). The impact of age on the reservation wage: the role of employment efficacy and work intention: a study in the Belgian context. Journal of Applied Gerontology, 34(3), NP83-NP112. https://doi.org/10.1177/0733464812473201

Dolton, P., \& O'Neill, D. (1995). The Impact of Restart on Reservation Wages and Long Term Unemployments. Oxford Bulletin of Economics and Statistics, 57(4), 451-470. https://doi.org/10.1111/j.1468-0084.1995.tb00034.x

EU-27 trade in goods with the Commonwealth of Independent States, 2000-2010 - Issue number 40/2011. [Online] Available: https://digitalcommons.bard.edu/senproj_s2018/358/

Haurin, D. R., \& Sridhar, K. S. (2003). The impact of local unemployment rates on reservation wages and the duration of search for a job. Applied economics, 35(13), 1469-1476. https://doi.org/10.1080/0003684032000081302

Hofler, R. A., \& Murphy, K. J. (1994). Estimating reservation wages of employed workers using a stochastic frontier. Southern Economic Journal, 961-976.

https://doi.org/10.2307/1060433

Kolev, A., \& Saget, C. (2005). Understanding youth labour market disadvantage: Evidence from south - east Europe. International Labour Review, 144(2), 161-187.

https://doi.org/10.1111/j.1564-913X.2005.tb00564.x

Krueger, A. B., \& Mueller, A. I. (2016). A contribution to the empirics of reservation wages. American Economic Journal: Economic Policy, 8(1), 142-79.

https://doi.org/10.1257/pol.20140211

Lentz, R., \& Tranaes, T. (2005). Job search and savings: Wealth effects and duration dependence. Journal of Labor Economics, 23(3), 467-489. https://doi.org/10.1086/430284

Malk, L. (2014). Determinants of reservation wages: Empirical evidence for Estonia. Eesti Pank. [Online] Available:

https://www.eestipank.ee/en/publication/working-papers/2014/82014-liina-malk-determinants 
-reservation-wages-empirical-evidence-estonia

Mohanty, M. S. (2005). An alternative method of estimating the worker's reservation wage. International Economic Journal, 19(4), 501-522.

https://doi.org/10.1080/10168730500382170

Prasad, E. (2001). The dynamics of reservation wages: preliminary evidence from the GSOEP. Vierteljahrshefte zur Wirtschaftsforschung, 70(1), 44-50.

https://doi.org/10.3790/vjh.70.1.44

Queralt, D. (2006). An empirical analysis of the reservation wage components. Sample: Unemployed and Inactive Women in Catalunya, 2001/2. [Online] Available: https://www.fbofill.cat/sites/default/files/1596.pdf

Sant, D. T. (1977). Reservation Wage Rules and Learning Behavior. The Review of Economics and Statistics, 43-49. https://doi.org/10.2307/1924902

Şentürk, İ. (2015). Determinants of Expected Wages of Unemployed Workers in Turkey. Modern Economy, 6(07), 808. https://doi.org/10.4236/me.2015.67076

Shimer, R., \& Werning, I. (2007). Reservation wages and unemployment insurance. The Quarterly Journal of Economics, 122(3), 1145-1185. https://doi.org/10.1162/qjec.122.3.1145

Western Balkans Labor Market Trends Report, (2017), World Bank \& WIIW Research Institute. [Online] Available:

http://pubdocs.worldbank.org/en/336041491297229505/170403-Regional-Report-Western-B alkan-Labor-Market-Trends-2017-FINAL.pdf

World Bank (2016), South East Europe Regular Report, Resilient Growth Amid Rising Risks, No.10, Washington DC/ [Online] Available:

http://pubdocs.worldbank.org/en/521981474898709744/SEE-RER-Report-Fall-2016.pdf

\section{Copyright Disclaimer}

Copyright for this article is retained by the author(s), with first publication rights granted to the journal.

This is an open-access article distributed under the terms and conditions of the Creative Commons Attribution license (http://creativecommons.org/licenses/by/3.0/). 